\title{
Deployment of Industrial Engineering in Japan after World War II
}

\author{
Tohsio Yamazaki ${ }^{1}$ \\ ${ }^{1}$ Professor, College of Business Administration, Ritsumeikan University, Osaka, Japan \\ Correspondence: Tohsio Yamazaki, Professor, College of Business Administration, Ritsumeikan University, \\ Osaka, Japan.
}

Received: March 6, 2018

doi:10.5539/ibr.v11n5p50

\begin{abstract}
This paper discusses the deployment of American-style management systems in Japan after World War II. One of the major American management methods implemented in many countries after the war was industrial engineering (IE), an advanced form of scientific management originating in the United States. Such American methods played an important role in production management and rationalization as well as the Ford system. The primary issue was the implementation of the work factor (WF) method and Methods Time Measurement (MTM) for the deployment of IE. Thus, this paper examines the deployment of IE in Japan in relation to the problems of work measurement and method engineering, the role of industrial engineers, and the influence of institutions on the implementation and promotion of IE, such as the Japan Iron and Steel Federation. Through these discussions, this paper clarifies the Japanese characteristics regarding the deployment of IE and their significance.
\end{abstract}

Keywords: Americanization, Industrial engineering (IE), management system, Methods Time Measurement (MTM), productivity movement, work factor

\section{Introduction: Research Topics}

In the period immediately following the end of the war, productive forces and economic might significantly differed between European nations and the US as well as between Japan and the US. Thus, "catching up" became one of the most pressing issues in each country. The deployment of US technology and management methods greatly contributed toward addressing this issue; the requisite conditions for achieving this goal were created with US guidance and assistance.

Japan as defeated nations in the World War II received significant American leadership and support after World War II. The United States played significant role in development of economies in European nations and Japan after the war. Japan developed its enterprises, industries, and economy by deployed and adapted technology and management methods from the United States and became a major trading country.

The primary characteristics of US management methods deployed in the 1950s and 1960s were (1) management and production systems (industrial engineering, statistical quality control, human relations, and the Ford system); (2) management education methods; (3) responses to markets coinciding with advancements in mass production (marketing and public relations); and (4) the divisional structure. However, the deployment of American management methods and systems varies widely between a specific management system and method as well as between industries and corporations. Situations in the deployment of American management methods also differed between countries.

This paper analyzes the deployment of industrial engineering (IE) in Japan. Among American management systems, IE, an advanced form of scientific management that originated in America and gained broad acceptance after World War II played an important role in production management and rationalization as well as the Ford system. When in looking at IE, we see that work studies consider it the next level of development (Kirchner 1970, p. 440), and that the US had a decisively leading role in the IE field. A Siemens US study trip report in 1963, the end of the productivity movement, noted that the predetermined time method then being implemented in the world of capitalism was without exception developed and tested in the US prior to being made public. For example, WF (work factor) was developed in the US in the mid-1930s (Siemens Archiv Akten, 16020, Aus Theorie und Praxis des Industrial Engineering in den USA. Bericht über eine Studienreise September/Oktober 1963 , p. 123), implemented after 1938, and then used internationally from 1952. In the International Management Conference held in September 1963, there was a discussion on issues of WF time standards and 
WF use [Bundesarchiv Koblenz, B393/27, International Conference on Work Factor Time Standards (26-27.9.1963)] . MTM (methods time measurement) was developed by H. B. Maynard, G. J. Stegemerten, and J. L.Schwab in the 1940s at Westinghouse (Siemens Archiv Akten, 16020, Aus Theorie und Praxis des Industrial Engineering in den USA, p. 33; Maynard et al. 1948), and spread in many countries after the war.

However, these changes included the adaptations of systems to local conditions based on an overall structure of and relationship with Japanese capitalism in business management. Many factors influenced the introduction of IE in this country. How business management in Japan changed with the deployment of US technology and management methods? Along with commonalities with the US, what types of unique developments emerged? How were US management methods reformed to accommodate Japanese conditions? And how were the Japanese management style and characteristics created? What was the significance of these developments? This paper describes how American-style management systems were implemented in Japan and the resulting changes in corporate management.

Many studies approach the deployment of IE in Japan. However, these studies do not always identify which elements of American and Japanese management methods were combined, how they were hybridized, and which factors determined the hybridization (for these studies see books and articles cited in this paper). It is very important to elucidate how Japanese-style business management and its particular characteristics, conforming to Japanese conditions while still bearing on the Japanese management style, surfaced during the deployment of the American management method from the perspective of structural analysis. This paper will consider the problems stemming from the Japanese method of conforming to the American method, impacted by traditional and cultural factors in business management as well as institutional factors, and its relationship to the structural characteristics of Japanese capitalism.

This paper first examines social and economic background regarding the deployment of industrial engineering in Japan in Section 2. Next, in Section 3, deployment of industrial engineering in Japan will be considered. Furthermore, based on the aforementioned discussion, the Japanese characteristics regarding the deployment of industrial engineering methods will be clarified in Section 4. In Section 5, concluding remarks will be indicated.

\section{Social and Economic Backgrounds Regarding the Deployment of Industrial Engineering in Japan}

This section considers the social and economic background regarding deployment of IE in Japan. According to a 1956 report by an iron and steel productivity inspection team, the introduction of IE was highly necessary based on the assumption that the key difference between the productivity between Japan and the United States was due to IE (Nihon seisansei honbu 1956, pp.1, 4-5, 21-23, 98-99). In 1957, a study group was established in the Japan Iron and Steel Federation by eight companies and guided by E L. Fuse, an IE expert. Two years later, the group formed a committee that promoted the deployment of IE (Nihon tekko renmei tekko jyunenshi henshu iinkai 1969, pp.595-597, Yawata seitetsu shashi hensan jikko iinkai 1980, p.32). A significant contribution of IE to the American industrial world was that it indicated certain standards (Nihon tekko renmei IE shiryo kenkyukai 1958, p.35).

However, in Japan, when implementing IE for measurement and management, such standards were lacking, even in the latter half of the 1950s (Tekkokai 1957, pp.34-35). As a result, the purpose of work measurement became increasingly important. For instance, at the Mitsubishi Electric Corporation, the person in charge of work measurement played a major role in IE at the end of the 1950s (Hachimaki 1958, p.30). Under such conditions, a WF business agreement was reached between the Japan Management Association and the Work-Factor Company in 1958, which laid the foundation for introducing WF to the business world (Konno 1982, p.227).

The competitive environment in which Japanese companies were involved also promoted the deployment of IE. More specifically, among several large businesses with similar powers, which belonged to six industrial groups, excessive competition, over-investment for plants and equipment, and newly formed business alliances raised the necessity to introduce IE (Noguchi et al. 1965, p.229). Moreover, in 1962, the introduction and systematization of IE became necessary in response to the intensification of international competition and trade liberalization. Thus, the number of companies that introduced IE dramatically increased (Noguchi 1968, p.195, Nihon tekko remei jimukyoku 1962, p.71). In the Japanese iron and steel industry, a substantial reduction in the number of workers would be problem, even though it could be used as an anti-recession measure to set the standard time spread (Yasui 1986, p.201). In this industry, there were aspects that exceeded those in the American industry, such as the number of indirect personnel, including those in design, investigation, transportation, and administration despite the existence of excellent equipment and machinery (Miyajima 1963, p.239). Therefore, minimizing costs through IE became an important issue.

Furthermore, the introduction of a flow production system and the development of innovation also raised the 
significance of deploying IE. In addition, under the continuing buildup of production with automation, adjustments in the time of each process became important cost-effective measures.

In the 1970s, IE was particularly deployed for labor savings, cost reductions, and personnel arrangement in several industries, such as the iron and steel industry, under a shift from high economic growth to low economic growth, which was brought on by the oil crisis (IE mondai kenkyukai 1975a, pp.77-78). In the electrical industry, the recognition was strong of the standardization and guarantee of quality, which had been indispensable with the mass mobilization of young women in the workforce, the deepening division of labor in the factory, and the thoroughness of the mass production system (through the use of conveyors) (IE mondai kenkyukai 1975b, p.99; IE mondai kenkyukai 1975c, p.139).

\section{Deployment of Industrial Engineering in Japan}

\subsection{General Conditions Regarding the Deployment of Industrial Engineering}

Based on these discussions, this section examines the deployment of IE methods in Japan. We first consider general conditions regarding the deployment of IE. The WF method was introduced in 1950 and adopted in the following years while MTM was first implemented in 1957 (Indasutoriaru enjiniaringu 1959, p.81; Miharada 1965, p.28; Tsusho sangyosho gorika shingikai 1967, p.62). In the latter half of the 1950s, the introduction and adaptation of IE in industrial enterprises advanced under the productivity movement. However, IE still lacked unity, and its development focused on operational management. During this stage, emphasis was primarily on human engineering, system engineering, and method engineering (Noguchi 1968, pp.170, 196, 207-208; Nihon tekko renmei jimukyoku 1962, p.71). By the end of the 1950s, the WF method began to spread (Ono 1959, p.60), playing an important role in method engineering (Ikenaga 1962, p.786).

However, even in this period, unlike in the United States, the organization of IE in Japan was incomplete. At that time, setting work standards and time standards and training industrial engineers were urgent issues (Nihon seisansei honbu 1960, pp.22, 39-40, 58, 133-135; Ozaki 1959, pp. 362, 366). This reflected the fact that, whereas industrial engineers in the United States were known as professionals, they were considered non-professionals in Japan (Omura 1962, pp.915, 926).

In this way, the completion and systematization of IE became necessary. However, rather than adjusting the contents of IE content, Japanese companies placed greater emphasis on reshuffling distributed management based on work standardization (time-motion studies). Thus, the systemization of IE was delayed. In addition, Japanese companies addressed various methodologies for work rationalization (e.g., production management, cost control, etc.). However, in this period, the concept of function as the focus of IE in a company was still not sufficiently established (Noguchi 1968, pp.171, 196-197; Noguchi et al. 1965, pp.224-225, 228; Indasutoriaru enjiniaringu kokunai shisatudan 1958, p.232).

IE was eventually established and systematized by integrating scientific management techniques in the 1960s. (Inoue 1976, p.28). For instance, in the iron and steel industry, whereas IE activities were initially limited to work improvement, the focus on standard setting eventually increased (Nihon tekko renmei jimukyoku 1962, p.71). Moreover, predetermined time standard systems (PTS) used in Japan included the WF method and MTM. By the mid-1960s, the use of the WF method became quite widespread, exceeding that of MTM (Quick and Ikenaga 1965, pp.1100-1101; Bijinesu 1960, pp.69, 73; Konno 1982, 227). In contrast, in the United States, the most widely used method was MTM (Nihon seisansei honbu 1960, p.102; Nihon seisansei honbu 1964, p.42; Konno 1982, p.227). Therefore, the deployment of IE greatly differed between the two countries.

Even in the 1970s, IE activities that extended into various fields, such as workmeasurement, work improvement, standardization, quality control, process control, and cost control, were independently performed in companies. There were no IE activities in which each measure was connected to one another and integrated as a total system (Ono 1970, pp.26, 31). It is possible to see the shift from individual applications to general and systematic adaptations of IE from the latter half of the 1960s to 1970 (Hibi 1975, p.30).

In Japan, the education of industrial engineers had already become an important issue in the early 1960s (Furukawa et al. 1961, p.103). However, as a 1967 survey pointed out, industrial engineers were not regarded as professionals, and their main tasks focused on methods. In many cases, industrial engineers in Japan were more inferior than those in the United States, and their time studies primarily used stopwatches (Taniguchi 1967, pp.1197-1200). In addition, the situation of factory engineers greatly differed in Japan and the United States. For example, in the United States, since numerous examinations regarding production aspects were performed before shifting to production, factory engineers were not always necessary. Conversely, in Japan, investigations regarding production technology were not sufficiently performed. As a result, technical issues frequently 
occurred during the start of production, and many factory engineers were required in order to solve such problems (Ueda 1967, pp.135, 137). By the mid-1960s, the standard and system for wage setting had become the focus of IE, and system improvements were mainly performed in the American iron and steel industry. In contrast, the design and improvement of a total system, which consisted of personnel, machinery, and materials, had become the focus of IE in Japan. However, the process of setting standards concerning personnel was still incomplete at this stage (Uchiyama 1966, p.34).

One cause for such incompleteness in IE in Japan was the low abilities of the industrial engineers (Takeda 1967, p.580). As a result, around the end of the 1960s, greater emphasis was placed on method study and improvement rather than work measurement. In addition, standard time was generally employed as the standard of efficiency measurement, the basis of production planning, the calculation of personnel, and cost estimation (Omura 1969, p.16; Shida 1968, p.11). IE focused on other aspects of business management, such as standardizing work or setting standard values for management purposes (Juji 1968, p.6).

Furthermore, the conditions surrounding the deployment of IE significantly differed among industries. For example, IE advanced the most in the iron and steel industry and in the processing and assembly industries, especially in the automobile industry and the electrical industry. Finally, the differences among companies were also significant. For instance, in the mid-1970s, among small and medium-sized firms, the use of modern IE methods was rare (Hibi 1975, p.31). Hence, the following section examines the introduction of IE in the main industries as well as their representative companies.

\subsection{Deployment of Industrial Engineering in the Main Industrial Sectors}

\subsubsection{Iron and Steel Industry}

In this industry, IE achieved results in the field of method engineering. Improving business affairs and performing standard setting were two pillars of IE (Nihon tekko renmei junenshi henshu iinkai 1969, pp.606-607). IE for quality improvement and cost reduction was introduced in the first rationalization plans from 1951 to 1955 and fully utilized as an IE system in the second rationalization plans from 1956 to 1960 . During this period, standardization for realizing consistency in production (under the introduction of automation technology) was promoted. Moreover, synthesization and systematization of IE were pursued, after which IE was introduced in earnest for the purposes of planning work duties, setting the standard amount of work, and overseeing its strict accomplishment (Inoue 1976 p.30). Furthermore, personnel assessments on a company-wide scale were implemented, and improvements in management functions, such as investigations regarding equipment capacity, process control, transportation management, and inventory control, became important (Nihon tekko renmei jimukyoku 1963, p.81).

The application of standard time to labor management developed the most around 1962, when personnel rationalization was necessary due to the recession at the time (Nihon tekko renmei junenshi henshu iinkai 1969, pp.607-608; Goji et al 1969, p.896). Thus, the reduction of workers based on the setting of standard time became the top priority in IE (Yasui 1986, p.207). During the 1960s, the importance of personnel rationalization, rationalization of contract management, and approach to management issues increased. Consequently, IE became increasingly important for top management (Nihon tekko renmei jimukyoku 1966, p.100; Nihon tekko renmei jimukyoku 1967, p.95). In fact, by the end of the decade, the scope of IE expanded into the design of management systems, analysis of management issues, productivity improvement, and cost reduction. IE was also applied to personnel rationalization in indirect departments (Nihon tekko renmei junenshi henshu iinkai 1969, pp. 605, 608). There were five overall goals: (1) improving work and equipment; (2) setting standard time for workers; (3) designing management systems; (4) providing consultations; and (5) other business-related activities. Furthermore, establishing regular personnel was an important part of many IE projects, followed by job and office work improvement, management of equipment, standard setting, and process control (Ono 1968, pp.65-670). Setting a standard time was applied to the new system of efficiency wages as well as conventional personnel assessments (Nihon tekko renmei jimukyoku 1968, p.103). From the late 1960s to the early 1970s, self-management activities played a significant role in method engineering and improving morale. Thus, IE that engaged in the promotion of self-management became increasingly important (Nihon tekko renmei jimukyoku 1972, p.80).

Cost reduction was also an important part of IE activities after 1973, especially during the oil crisis (Nihon tekko renmei jimukyoku 1974, p.80: Nihon tekko trenmei jimukyoku 1975, pp.100-101; Nihon tekko renmei jimukyoku 1976, pp.65-66; Nihon tekko renmei jimukyoku 1978, p.66). Subsequently, the role of IE was important in the implementation of fixed-cost reduction measures during the 1980s. To promote production efficiency in both the upstream and downstream processes of the organization, IE continued to focus on improvements from all perspectives (Tekko no IE 1984, pp.14-15). 


\subsubsection{Automobile Industry}

The introduction of WF as a new method of standard setting made an impact, especially with regard to the ratio of labor costs to production costs, which was very high in the assembly industry (Kikuchi 1968, p.608; Sakano 1963, pp.220, 223-225). For instance, at the Nissan Motor Corporation, due to new product releases, constantly changing automobile models, and new factory openings, various problems, especially those related to factory layout and material handling, were widespread. In addition, issues related to cost reduction and equipment investment occurred (Takai et al. 1968, p.8; Omura 1959c, p.450; Sakano 1963, p.225). Under such conditions, the training of IE staff became an important issue. By the end of the 1950s, top management, such as those at the Toyo Kogyo Corporation, began to recognize the necessity of having IE staff members (Omura 1959c, p.450).

In 1955, at the Nissan Motor Corporation, imbalances in setting standard time via the stopwatch method and the adoption of a group premium wage system resulted in constant complaints (Tsusho sangyosho gorika shingikai 1967, p.73; Kyushu indasutoriaru enjiniaringu kokunai shisatsudan 1959, p.18). In response, the company completed a master table of all work-related activities, and a standard time was set for every section. The company-wide application of standard time via the WF method had begun, and the management system was established. In this case, suggestions for work improvement and efficiency control were the main fields of IE. In addition, the company pursued cost reductions for parts purchased from other companies. Such reductions were based on the guidance of work measurement and improvement methods for parts companies, decisions regarding various costs according to value analysis (VA), and the establishment of specialized lines (Nissan jidosha kabushiki gaisha somubu chosaka 1965, p.294; Kyushu indasutoriaru enjiniaringu kokunai shisatsudan 1959, p.18; Tsusho sangyo sho gourika shingikai 1967, pp.62-63, 79; Omura 1959b, pp.101, 103-104; Sakano 1963, pp.202, 206). Management of the number of work hours (mainly based on standard time) was also implemented. Whereas the WF method was primarily adopted for manual work, machining time was based on technological considerations and statistical methods (Tsusho sangyosho gorika shingikai 1967, pp.65-66).

IE departments at central-office levels were eventually established. Such departments not only played a role in top management but also engaged in IE activities at the factory level. (Tsusho sangyo sho gourika shingikai 1967, p.64). For example, at the Toyo Kogyo Corporation, a master table related to the standardization of work was created in 1949, after which the WF method was adopted in 1955. In 1958, work sampling was introduced and standard time was established. Moreover, improvements were made in measurement precision, and the rate of operation was realized (Toyo kogyo kabushikigaisha gojunenshi 1972, pp.301-302).

\subsubsection{Electrical Industry}

Whereas time studies utilized the stopwatch method until the mid-1950s, conversion to the WF method was achieved by the end of the 1950s. However, in this particular industry, MTM was still in its infancy; thus, it was not adopted. At that time, the representative companies in the field of IE continued to emphasize the following aspects: work standards and standard time, cost reductions, plant layout, standardization, and suggestion systems. Moreover, quality standards were established, after which technical alliances with foreign firms had a significant influence on such standards. This was a characteristic typically found in the electrical industry (Sato 1959, pp.266-267).

However, there were differences between the sections regarding mass-produced products and those related to individual order production. For example, for home appliances, in which mass production via conveyors was dominant, setting a standard time was achieved by the WF method, and in many cases, standard time was used for both process and personnel planning (Tsusho sangyosho kigyoukyoku 1969, p.105). In contrast, as large-sized individual orders were produced, the Kawasaku factory of the Fuji Electric Corporation employed the stopwatch method in time studies. It was not until the early 1960s that the WF method and MTM were adopted (Omura 1961, p.194).

Regarding individual enterprises, in 1950, the Mitsubishi Electric Corporation introduced the WF method to improve the estimation techniques of elementary motion. In 1951, the company introduced a training program for work-factor engineers, and by 1954, the WF value was adopted as the standard time value and company-wide standard time was established for both mass production and individual production (Mitsubishi denki kabushiki gaisha shashi hensansitsu 1982, pp.106, 275). In the Itami factory of this company, the core IE activities from the late 1950 s to the early 1960 s included the creation of a work-study subsection, which was responsible for conducting work performance measurements and making method improvements (Omura 1960, pp.170-172). In the mid-1960s, the Matsushita Electric Corporation particularly emphasized traditional IE rather than modern IE. This company also made an effort to improve material handling, realize premeditated production, shorten production schedules, and cut down the overall production period by introducing method engineering and conveyor systems (Daisanji IE kokunai shisatsudan 1965, p.18). 


\section{Japanese Characteristics in the Deployment of Industrial Engineering}

Based on the foregoing discussions, this section will clarify Japanese characteristics in the deployment of industrial engineering. We can point out the following items constitute the main characteristics of IE deployment In Japan, IE was promoted and developed in solidarity with the business world, as seen in the IE study committee in the iron and steel industry. There were no such efforts in foreign countries (Nihon tekko renmei junenshi henshu iinkai 1962, p.612). This reflected the situation in which the results of process studies by institutions, such as REFA in Germany that had traditionally played an important role since the rationalization movement in the 1920s, did not exist in Japan. Regarding supervisors at the workplace, first-line supervisors, which are comparable to foremen in the United States or meisters in Germany, did not exist in Japan. This shows that traditional IE was not utilized in factories and that the deployment of IE was still a rudimentary activity (Juji 1968, pp.7-8). In addition, foremen in the United States had considerable authority compared to those in Japan (Kasahara and Tezuka 1968, p.16; IE 1968, p.11).

Thus, the general foreman system was adopted in the iron and steel industry, which greatly advanced the deployment of IE. IE was systematically implemented in the workplace under the establishment of line and staff organization by the general foreman system. This was introduced in the Yawata Iron and Steel Corporation for the first time in 1958, after which it prevailed in many other companies. Substantial power over subordinates was given to general foremen, and the function of IE was mainly absorbed into staff organization. This process, in which the line manager (led by the general foreman) assumed the central role, became the primary function of IE (Yawata seitetsu kabushiki gaisha shashi hensan iinkai 1981, pp.706-707; Katsui 1968; Noguchi 1968, p177; Komatsu 1968; Sumitomo kinzoku kogyo kabushiki gaisha shashi henshu iinkai 1967, pp.169-170; Dai niji indasutoriaru enjiniaringu kokunai shisatsudan 1959, pp. 301-306). Thus, we can see an important character in that the general foreman, specified as a principal player in IE, was sometimes given responsibility for cost control, cost reductions, and overall labor management.

In the field of IE in Japan, there were problems related to work measurement (Ono 1968, p.70). However, the work measurement that was so popular in the United States and Germany was not thought to be a fit for Japan, and many corporations focused entirely on continuous method engineering (Juji 1969, p. 2). This showed that IE played a considerable role in the development of various improvement activities, which had been expanded in Japan. Unlike in the United States, where standard time was set in relation to wages and working hours, in Japan, it was also important to use the number of work hours as the standard for making improvements and evaluating results (Juji 1973a, p.9; Juji 1973b, p.47). Furthermore, upon implementation of the work-factor method, reforms were made to wage systems, particularly to wage rates along with job analysis (Inoue 1976, p. 29).

In the United States, "work standard" means the terms of a worker's contract. In American-style work management, work standard and work time had an apparent meaning. Conversely, in Japanese-style work management, the term only showed the content of the work to be performed. Thus, it was more effective to use standard time not as a standard for evaluating the worker but as the "time as the goal for a given work standard." In the United States, in job design, the necessary work for an organization is decided according to the nature of the work, after which it is assigned to an individual. In this regard, job design forms the terms of the contract. However, Japanese-style job design presents the overall goal of the work and leaves a certain amount of flexibility for the individual (Juji 1973c, pp.100-102).

Regarding the use of a predetermined time standard system (PTS), for example, work improvement, cost accounting, and cost estimate had the highest applications during the 1950s in both Japan and the United States. However, the application of IE in setting work methods (before shifting to production) was lower in Japan than in the United States. In contrast, such work planning and decisions regarding personnel were higher in Japan than in the United States. In this case, emphasis on the use of IE differed greatly between the two countries (Indasutoriaru enjiniaringu 1959, p.85).

In addition, IE was rolled out in connection with labor management functions. For example, different employment practices among Japanese corporations, such as the seniority wage system and lifetime employment, led to inconsistent labor targets for IE and differences among other IE elements (Ueda et al. 1967, p.539).

There were many cases in which American methods of manager education and supervisor training, such as TWI (Training within Industry) and MTP (Management Training Program), were used to implement IE. For instance, at the Toyota Motor Corporation, TWI and MTP were used for full-scale standardization, and they were also introduced in subcontracting enterprises to make company-wide improvements (Toyota jidosha kogyo kabushiki gaisha shashi henshu iinkai 1958, p.417; Toyota jidosha kabushiki gaisha 1987, p.227; Wada 2009, pp.521-524; Fujimoto 1997, pp.69, 117). The Yawata Iron and Steel Corporation also established a standard work method 
(Nihon tekko renmei sengo tekkoshi henshu iinkai 1959, p.997). At the Fuji Electric Corporation, the introduction of TWI for training first-line supervisors became an effective means of developing IE (Fuji denki seizo kabushiki gaisha 1974, p.225). Meanwhile, IE was implemented for quality-control activities. For example, at the Kobe Steel Corporation, IE activities were developed as a part of its total quality control (TQC) effort to improve the company's constitution (Tekkokai 1964, p.21).

IE was originally developed with the two pillars of work measurement and method improvement. However, it was eventually applied to a wider field in Japan (Wada and Juji 1967, p.519: Nakayama et al 1960, pp.121-122). We can also see an important characteristic of IE in Japan since its activities could be divided into three stages: (1) a central office IE department, which offers services for top management and general managers; (2) an IE department, which provides services to the heads of production and plant managers; and (3) an IE section, which offers services for individual workplaces (Daisanji IE kokunai shisatsudan 1965, p.153). In the mid-1960s, most of the activities were implemented in Japan in the third stage, with work improvements, setting a standard time, work sampling, work measurements, cost estimations, and design and management of inspection instruments as the core functions. In the second stage, system engineering was carried out to some extent, even though it was not as wide as the third stage (Ueda 1966, pp.1277-1278). However, IE was not effectively diffused from the top to the bottom levels of management (Block 1964, p.515).

Although the use of IE methods increased, there were still many problems with regard to IE ideas, recognition of IE by line managers, and operations by industrial engineers. IE efforts were naturally obstructed by such issues (Daisanji IE kokunai shisatudan 1965, preface). The following five points can be considered relevant problems in the field of IE: (1) activities regarding operation systems and control systems; (2) activities related to troubleshooting and making improvements in existing systems; (3) the rate of IE activities, which were performed depending on the demands of line managers; (4) cases in which the number of personnel in the IE section was high; and (5) the fact that company-wide IE was insufficient or not established (Daisanji IE kokunai shisatsudan 1965, pp.177-178). Furthermore, in Japan, although the number of universities with IE sections in engineering departments increased, the spread of IE education was considerably late compared to that in the United States (Daisanji IE kokunai shisatsudan 1965, pp.146-147).

In Japan, the broad existence of parts companies and cooperating firms, such as subcontracting firms, supported the production system of large enterprises. Thus, detailed rationalization and improvement activities through the introduction of IE were promoted (Tsusho sangyosho gorika shingikai 1967, p.79; Miyajima 1967, p.331). Guidance and instruction in standard setting by large enterprises was a significant reason for building close inter-firm relationships and establishing production networks under Japanese subcontracting firms.

In the introduction of IE, influences from differences in the material traits and climates in Japan and the United States were significant. Among the many management techniques introduced from the United States, management methods directly related to "things," such as quality control (QC) and value analysis (VA), were taking root by the latter half of the 1960s. In contrast, management techniques related to human mental activities, such as IE, did not achieve good results. It is possible that such differences between Japan and the United States were one of the major causes. In contrast with American companies, in which work began after responsibilities were prescribed and the authority of each member was predetermined, in Japanese enterprises there were many cases in which a vague organizational system was in place and responsibilities were discussed after the work had begun (Dai sanji IE kokunai shisatsudan 1965, p.150; Tshusho sangyosho kigyokyoku 1969, pp.105-106, 133).

Even at the end of the 1960s, the recognition of management, including IE, was insufficient since the responsibilities of front-line supervisors were still uncertain. Thus, it was necessary to establish management standards for front-line supervisors and clarify certain responsibilities (Tsusho sangyosho kigyokyoku 1969, p.112). In the United States, based on pragmatic thinking, companies searched for a solution to the problem by focusing on methods without establishing particular theorems and systems. In other words, once a new method was discovered, it was widely used as the "standard." In contrast, such thought and spirit of pragmatism did not exist in Japan (Kuroita 1959, pp.317-319).

\section{Concluding Remarks}

From the perspective of this paper, to improve productivity at the time of introducing the American management method, the measures and elements that were directly related to improving "efficiency" (economic efficiency) were concerned with the development of productive forces; therefore, these principles were relatively, proactively, and widely introduced. One of such cases can be seen in the basic principles of industrial engineering, such as production management and labor management.

In contrast, there were many aspects of American-style management that did not necessarily conform at the time 
to the conditions in Japan. These included aspects with American characteristics, such as the culture and relationships shared among labor and management, value for management, management style, and management tradition/culture. Therefore, in many cases, there was strong resistance and opposition that prevented the introduction of these aspects, and it was only possible to introduce them by modifying them in the process.

Furthermore, in reality, there were many cases wherein the Japanese method of management was pursued, even though mechanisms and principles for improving efficiency were introduced. In particular, due to the influence of Japanese corporate traditions and management values and various systemic factors within companies, and industrial relations, many Japanese companies sought the Japanese-style adaptation. Zeitlin's research emphasizes the active altering of the American Model. Here, Zeitlin points out that there was selective adaptation of American technology and management that was tailored to the local environment, and that creative modifications and innovative hybridizations were observed. However, these modifications and hybridizations should not be understood as a negative phenomenon or indications of domestic resistance to the transfer process, or even as the mark of inevitable compromise. Rather, they should be realized in the positive light, i.e., the modifications originate from experimental work and innovative learning (Zeitlin 2000, pp. 11, 15-20).

Thus, the people involved in the industry took advantage of their experience, accumulated while decomposing, modifying, and re-concentrating the elements of the American model to best fit the local environment. By doing so, they reinterpreted, modified, and at times changed their country's practices and systems. Japanese industrialists had significant existing knowledge of American-style practices. Zeitlin points out that Japanese industrialists' prior familiarity with American-style practices enabled them to treat US technology and management not as a unitary model to be imitated wholesale, but rather as a suggestive point of departure for selective adaptation, creative modification, and innovative hybridization (Zeitlin 2000, pp. 38, 40-41). Mix of American and Japanese factors in management systems can be seen in introduction of the job-based wage under the deployment of the work-factor method.

When considering the deployment of IE in relation to important factors that effected on the implementation of such American management methods, influences of management values and management traditions and cultures, such as management values based on Japanese collectivism and mutual trust between company members and those emphasizing relationships between management and labor based on a weak contracting view can be seen in the following points. Work standards tended to be used not as the terms of workers' contracts but a loose standard, which was deeply concerned with characteristics of Japanese improvement activities. Standard work time was used as a benchmark in establishing goals of job improvement by general foremen and evaluating the results. Management values emphasizing the role of production spots and relationships between management and labor based on weak contracting view (organization and its operation in which relations of authorities and responsibilities was unclear) influenced the implementation of IE.

Next, examining the institutional factors impacting the Japanese-style of adaptation in the process of Americanization, special systems such as subcontracting system also influenced the deployment of American management methods. Such cases can be seen in the deployment and modifications of IE in subcontracting firms and affiliated companies under the guidance of large enterprises that were at the top of the pyramid of subcontracting system. Other cases can be seen in the role of business associations in promoting deployment of IE and influence of management system such as the general foreman system.

In relation to the characteristics of the structure of productive forces prior to WWII, delay in the development of productive forces in the heavy industries and the process and assembly industries before the war was prominent. These industrial sectors rapidly expanded after the war. Introduction of the flow production system and innovations including automation promoted the deployment of IE methods. IE was implemented as various rationalization measures, such as production control and cost control for the modernization of production and to decrease costs via rapid development of productive forces.

When comparing conditions in foreign country, Japanese characteristics in the deployment of IE can be clearer. For instance, in Germany, the issues of various materials and the establishment of ideas related to the definition, classification, and subdivision of standard time by REFA contributed to improvements at the industry level (Hartmann 1963, p. 125; Schlaich 1969, p. 234; Hämmerling 1960, p. 127; Schwartmann 1975, p. 205). In contrast, such a technically authoritative national organization did not exist in Japan (Hamabe 1961, p.46), and management centers and IE centers were only established during the research boom (Omura 1959a, p.33). Such differences had a significant effect on the introduction and development of IE in both countries.

Regarding the conditions in Germany, we see that the dissemination of IE was related to REFA activities, and was also greatly affected by US-based IE. REFA had researched and examined various predetermined time 
methods including MTM and WF for a long time, and as a result decided to support WF, obtaining a license to use and disseminate the method (Jaeckel 1961, p. 223, p. 223; Pilz 1961, p. 124). However, REFA did not, for the most part, deprioritize its own systems in promoting WF. In relation to the aspect of hybridization, we observe the following mix of American and German factors in management and production systems. Industrial engineering methods such as the Work-Factor Method and Methods-Time Measurement were incorporated into the traditional German REFA system. As a result, these US methods were not widely adopted in German industry, unlike countries such as Sweden, where the creator of MTM, H.B. Maynard and his consulting firm, were highly successful in selling the method to corporations (Kipping 2004, p 36). Thus, regarding the broad spread of American IE methods, a delay can be seen compared to Japan.

\section{References}

Bijinesu. (1960). Kindai keiei no hanagata. IE no subete. Bijinesu, 4(5), 67-79.

Block, S. M. (1964). "Dentoteki” IE to "gendaiteki” IE no baransu wo kataru. Indasutoriaru enjiniaringu, 6(6), 514-520.

Dai niji indasutoriaru enjiniaringu kokunai shisatsudan. (1959). Dai niji indasutoriaru enjiniaringu kokunai shisatsudan hokokusyo. Tokyo, Nihon seisansei honbu, Nihon indasutoriaru enjiniaringu kyokai.

Dai sanji IE kokunai shisatsudan. (1965). Nihon ni okeru IE no doko-Dai sanji kokunai shisatsudan hokokusyo - . Tokyo, Nihon indasutoriarugu enjiniaringu kyokai, Kanto indasutoriaru enjiniaringu kyokai.

Fuji denki seizo kabushiki geisha. (1974). Fuji denki shashi II (1957 1973). Tokyo, Fuji denki seizo kabushi geisha.

Fujimoto, T. (1997). Seisan shisutemu no shinka ron. Toyota jidosha ni miru soshiki noryoku to sohatsu purosesu. Tokyo, Yuhikaku.

Furukawa, H., Maeda, S., Wada, E, Kogure, M.,Ssakai, S., \& Hachimaki, N. (1961). Obei to wagakuni ni okeru IE kyoiku no genjyo. IE Review, 9, 103-122.

Goji, K. et al. (supvr), Noda, K. (ed.) (1969). Gendai keieishi. Tokyo, Nihon seisansei honbu.

Hachimaki, N. (1958). Denki kikai kogyo to indasutoriaru enjiniaringu-Wagakuni denki kikai kogyokai ni okeru IE to sono tekiyo no jissai-. $P R, 9(2), 27-32$.

Hamabe, K. (1961). Kokkateki na kiban wo motsu doistu no ukeoi seido. Wagakuni tono konpontekina soiten ni tsuiteno kosatsu. Indasutoriaru enjiniaringu, 3(6), 457-462.

Hämmerling, F. (1960). Die Mechanisierung von Montagen in der Elektroindustrie. In: Brandt, L., Gardellini, R., King, A., Lambilliotte, M. (eds.) Industrielle Rationalisierung 1960. Dortmund, Verkehrs- und Wirtschafts-Verlag.

Hartmann, H. (1963). Amerikanische Firmen in Deutschland: Beobachtungen über Kontakte und Kontraste zwischen Industriegesellschaften. Opladen, Westdeutecher Verlag.

Hibi, S. (1975). Seisan kanri ron. Tokyo, Dobunkan shuppan.

IE (1968). Foaman no nichi • ou • bei kakusa wo kataru. Kotonaru keiei sanka no igi to kengen. IE, 10(5), 8-17.

IE mondai kenkyukai. (1975a). Gendai IEr no isiki to sono jittai, Tekko hen. IE Review, 16(3), 77-79.

IE mondai kenkyukai. (1975b). Gendai IEr no isiki to sono jittai, Denki sangyo hen. IE Review, 16(4), 99-101.

IE mondai kenkyukai. (1975c). Gendai IEr no isiki to sono jittai-Tekkogyo to denki sangyo ni okeru IE to ningen mondai-. IE Review, 16(5), 138-140.

Ikenaga, K. (1962). Seisan wo takameru kihonteki IE katsudo. Seikosha ni okeru sagyo hyojunka. Indasutoriaru enjiniaringu, 4(8), 785-790

Indasutoriaru enjiniaringu kokunai shisatsudan. (1958). Indasutoriaru enjiniaringu kokunai shisatsudan hokokusho. Tokyo, Nihon seisansei honbu.

Indasutoriaru enjiniaringu. (1959). PTS (kitei jikan hyojun) ho wa do katsuyo sarete iruka. Nichibei no PTS hikaku: Factory shi ga chosa shita Amerika 132 sha to honsi ga chosa shita 38 sha tono hikkau. Indasutoriaru enjiniaringu, 1(2), 81-90.

Inoue, H. (1976). Nihon ni okeru IE no tenkai to mujun. Gijutsu to ningen, 6, 26-34.

Jaeckel, B. (1961). 10 Jahre REFA-Bundesverband. REFA-Nachrichten, 14(6), 221-226. 
Juji, S. (1968). Rain kanbu no IE jissen ron. Ko sureba teichaku suru. Indasutoriaru enjiniaringu, 10(2), 4-9.

Juji, S. (1969). Futatsu no sinro wo toru korekarano IE. IE, 11(3), 2-5.

Juji, S. (1973a). Koten IE wa foaman no mono. IE, 15(5), 3-10.

Juji, S. (1973b). Nihonryu wo tsukuridasu tameni. Tokuina nihon no manejimento no ninshiki kara. IE, 15(11), 47-53.

Juji, S. (1973c). Hito wo ikasu tameni wa mazu soshiki kaihatsu wo. IE, 15(12), 97-104.

Kasahara, S., \& Tezuka, N. (1963). Amerika no IE no genjyo. IE Review, 20, 5-29.

Katsui, H. (1968). Atarashii sagyocho wa kono yoni sodatsu. IE, 10(5), 18-24.

Kikuchi, T. (1968). Kakusya ni okeru IE no jissi rei: Kikai kogyo ni okeru jissi rei. A sha no jirei. In: Nihon indasutoriaru enjiniaringu kyokai (ed.), IE giho hando bukku. Tokyo, Maruzen, pp.559-603.

Kipping, K. (2004). 'Importing' American ideas to West Germany, 1940s to 1970s. From associations to private consultancies. In: Kudo, A., Kipping, M., Schröter, H G. (eds.), German and Japanese business in the boom years. Transforming American management and technology models. London, Routledge, pp 30-53.

Kirchner, J. H. (1970), Förderung der Produktivität in Mittel- und Kleinbetrieben durch das Arbeitsstudium. REFA-Nachrichten, 23(6), 440.

Komatsu, H. (1968). Sagyocho seido. Tokyo, Rodo horei kyokai.

Konno, T. (1982). WF (Work Factor) ho oyobi MTM no donyu. In: Nihon noritsu kyokai (ed.), Keiei to tomoni. Nihon noritsu kyokai konsarutingu gijyutsu yonjunen. Tokyo, Nihon noritsu kyokai, pp 226-228.

Kuroita, S. (1959). IE to kokuminsei. In: Sakamoto, F., Noda K, F, Matsuda T, Uno, M. (supvr), Indasutoriaru enjiniaringu. Tokyo, Chuo koronsha, pp 317-322.

Kyushu indasutoriaru enjiniaringu kokunain shisatsudan. (1959). Kyushu indasutoriaru enjiniaringu kokunain shisatsudan hokokusho. Fukuoka, Nihon seisansei honbu, Seisansei kyushu chiho honbu.

Maynard, H. B., Stegemerten, G. J., \& Schwab, J. L. (1948). Methods-Time-Measurement. New York, NY: McGrow-Hill.

Miharada, S. (1965). IE heno kaigan to sono tenkai. Bijinesu, 9(4), 28-29.

Mitsubishi denk kabushiki gaisha shashi hensansitsu. (ed.) (1982). Mitsubishi denki shashi. Soritsu rokujushunen. Tokyo, Mitsubishi denki kabushiki geisha.

Miyajima, S. (1963). Tosha no IE katsudo-Kakudai sareta yakuwari wo motta IE bu no setti to sono kino-<Sumitomo kinzoku kogyo kabushiki gaisha>-IE Review, 23, 229-240.

Miyajima, S. (1967). IE wo seiko sasu niwa IE katsudo no tenkai . IE Review, 8(6), 325-334

Nakayama, T., Niizaki, K., Suzuki, T., Sato, R., Kawashima, M., Iwai, O., Kimura, M. (1960). IE katsudo no genjyo to mondaiten Zoku. Indasutoriaru enjiniaringu, 2(2), 121-128.

Nihon seisansei honbu. (ed.) (1956). Tekko. Tekko seisansei shisatsudan hokokusho. Tokyo, Nihon seisansei honbu.

Nihon seisansei honbu. (ed.) (1960). Amerika no indasutoriaru • enjiniaringu-Dai niji IE senmon shisatsudan hokokusho-. Tokyo, Nihon seisansei honbu.

Nihon seisansei honbu. (ed.) (1964). Indasutoriaru enjiniaringu. Indasutoriaru manejimento senmon shisatsudan hokokusho. Tokyo, Nihon seisansei honbu.

Nihon tekko renmei IE shiryo kenkyukai. (1958). Indasutoriaru • enjiniaringu no kenkyu to donyu ni tsuite. $P R$, 9(2), 33-40.

Nihon tekko renmei jimukyoku. (1962). Showa sanjurokunen no nihon tekkogyo kaiko. Tekkokai, 12(5), 6-78.

Nihon tekko renmei jimukyoku. (1963). Showa sanjunananen no nihon tekkogyo kaiko. Tekkokai, 13(5), 12-89.

Nihon tekko renmei jimukyoku. (1966). Showa yonjunen no nihon tekkogyo kaiko. Tekkokai, 16(5), 22-107.

Nihon tekko renmei jimukyoku. (1967). Showa yonjuichnen no nihon tekkogyo kaiko. Tekkokai, 17(5), 12-103.

Nihon tekko renmei jimukyoku. (1968). Showa yonjuninen no nihon tekkogyo kaiko. Tekkokai, 18(5), 12-107.

Nihon tekko renmei jimukyoku. (1972). Showa yonjurokunen no nihon tekkogyo kaiko. Tekkokai, 22(5), 12-110. 
Nihon tekko renmei jimukyoku. (1974). Showa yonjuhachinen no nihon tekkogyo kaiko. Tekkokai, 124(5), 16-110.

Nihon tekko renmei jimukyoku. (1975). Showa yonjukyunen no nihon tekkogyo kaiko. Tekkokai, 125(5), 16-119.

Nihon tekko renmei jimukyoku. (1976). Showa gojunen no nihon tekkogyo kaiko. Tekkokai, 26(5), 6-93.

Nihon tekko renmei jimukyoku. (1978). Showa gojuninen no nihon tekkogyo kaiko. Tekkokai, 28(5), 2-97.

Nihon tekko renmei sengo tekkoshi henshu iinkai. (ed.) (1959). Sengo tekkoshi. Tokyo, Nihon tekko renmei.

Nihon tekko renmei tekko junenshi henshu iinkai. (ed.) (1969). Tekkko junenshi-Showa sanjusannen yonjuninen. Tokyo, Nihon tekkko renmei.

Nissan jidosha kabushiki gaisha somubu chosaka. (ed.) (1965). Nissan jidosha sanjunenshi. Showa hachinen-Showa sanjuhachinen. Yokohama, Nissan jidosha kabushiki gaisha.

Noguchi, T. (1968). Seisan kanri no keieigaku. Tokyo, Zeimu keiri kyokai.

Noguchi, T., Ishizaka, I., Sekiguchi, M., \& Kojima, S. (1965). Keiei kanri soron. Tokyo, Chuo keizaisha.

Omura, M. (1959a). Gijutsu senta wo chusin ni IE katsudo wo tenkai. Fuji tsushinki kawasaki kojyo. Indasutoriaru enjiniaringu, l(1), 32-39.

Omura, M. (1959b). Gijutsubu wo chushin ni haba no hiroi IE katsudo wo tenkai. Nissan jidosha honsha kojyo. Indasutoriaru enjiniaringu, 1(2), 97-104.

Omura, M. (1959c). Sujimichi no totta kanri shisutemu wo mezasu-Toyo kogyo kabusiki gaisha一. Indasutoriaru enjiniaringu, 1(7), 445-454.

Omura, M. (1960). Soshikika sareta zenshoteki IE katsudo wo tenkai-. Mitsubishi denki itami seisakusho-. Indasutoriaru enjiniaringu, 2(3), 165-177.

Omura, M. (1961). Zosan taisei ni michakku sita IE katsudo. Fuji denki seizo kabusiki gaisha Kawasaki kojyo. Indasutoriaru enjiniaringu, 3(3), 189-198.

Omura, M. (1962). Nichibei no IE hikaku. Sono honshitsuteki sai bunseki wo kokoromiru. Indasutoriaru enjiniaringu, 4(10), 914-926.

Omura, M. (1969). Jittai kara mita nanajunendai no IE katsudo no hoko. Kakudai suru tekiyo ryoiki to zoshin suru kino. $I E, 11(7), 11-17$.

Ono, S. (1959). WF ho niyoru hyojyun jikan settei rei. Indasutoriaru enjiniaringu, 1(1), 60-67.

Ono, S. (1968). Kakusya ni okeru IE no jisshi rei. Tekko kogyo ni okeru jissirei: Tekkogyo ippann ni okeru rei. In: Nihon indasutoriaru enjiniaringu kyokai (ed.) IE giho hando bukku. Tokyo, Maruzen, pp.659-680.

Ono, S. (1970). Sogoteki IE katsudo no tenkai wo. IE, 12(10), 26-31.

Ozaki, T. (1959). Amerika no IE katsudo to nihon no genjyo. Indasutoriaru enjiniaringu, 1(6), 362-366.

Pilz, H. E. (1961). Die Einführung des Work-Factor-System in Deutschland. REFA-Nachrichten, 14(4), 124-125.

Quick, J. H., \& Ikenaga, K. (1965). WF to sagyo sokutei. Soshisha wo mukaete sono sinpo wo kataru. Indasutoriaru enjiniaring, 7(12), 1100-1106.

Sakano, T. (1963). Tosha no kosuto daun hosaku to IE <Nissan jidosha kabusiki gaisha>. IE Review, 23, 219-228.

Sato, R. (1959). Denki kogo. In: Sakamoto, F., Noda K, F, Matsuda T, Uno, M. (supvr), Indasutoriaru enjiniaringu. Tokyo, Chuo koronsha, pp 263-270.

Schlaich, K. (1969). Die Anpassung der Aufgaben und Methoden des Arbeitsstudiums an die wirtschaftliche und technische Entwicklung. REFA-Nachrichten, 22(4), 229-234.

Schwartmann, J. (1975). Praktische Arbeitsgestaltung in der Automobilindustrie. REFA-Nachrichten, 28(4), 205-207.

Shida, M. (1968) Nihon no IE koristsu wa naze hikui. Kigyo kokendo wa beikoku no sanbun no ichi ! IE, 1O(3), $10-16$.

Sumitomo kinzoku kogyo kabushiki gaisha shashi henshu iinkai (ed.). (1967). Sumitomo kinzoku kogyo saikin junenshi. Osaka, Sumitomo kinzoku kogyo kabushiki gaisha. 
Takai, K., Tanaka, T., Akiniwa, M., Kimura, Y., \& Kawase, T. (1968) IE no kibo wo kataru ( I ). IE Review, 9(1), 6-13.

Takeda, T. (1967). Kihonteki IE katsudo no jissen wo teishyo suru. Indasutoriaru enjiniaring, 9(6), 579-584.

Taniguchi, K. (1967). Jittai chosa yori mita kigyonai IE katsudo no nichibei hikaku. Indasutoriaru enjiniaringu, 9(12), 1196-1205.

Tekko no IE. (1984). Showa gojuhachinen tekko kakusha no IE katsudo. Tekko no IE, 22(2), 12-17.

Tekkokai. (1957). Indasutoriaru enjiniaringu to nihon no tekkogyo. Tekkokai, 7(11), 34-43.

Tekkokai. (1964). Wagasha ni okeru IE katsudo no genkyo. Kabushiki gaisha Kobe seikosho no maki. Tekkokai, 14(6), 21-23.

Toyo kogyo kabushiki gaisha gojunenshi hensan iinkai. (ed.) (1972). 1920-1970 Toyo kogyo gojunenshi-Enkaku hen-. Huchu, Toyo kogyo kabushiki gaisha.

Toyota jidosha kabushiki gaisha. (ed.) (1987). Sozo kagirinaku. Toyota, Toyota jidosha kabushiki gaisha.

Toyota jidosha kogyo kabushiki gaisha shashi henshu iinkai. (ed.) (1958). Toyota jidosha nijunenshi. Tokyo, Toyota jidosha kogyo kabushiki gaisha.

Tsusho sangyosho gorika shingikai. (ed.) (1967). IE no susumekata. Tadashii donyu to katsuyo. Tokyo. Nihon noritsu kyokai.

Tsusho sangyosho kigyokyoku. (ed.) (1969). Kokusaika jidai ni okeru wagakuni kigyo keiei no kodoka ni tsuite. Tokyo, Tsusho sangyosho kigyokyoku.

Uchiyama, T. (1966). Manejimento no kaizen. Tekkokai, 16(2), 28-35.

Ueda, S. (1966). IE maindo. Nihon kikai koggakaishi, 69(573), 1276-1280.

Ueda, S. (1967). IE no donyu to tenkai ni tsuite. IE Review, 8(3), 135-143.

Ueda, S., Tsumura, T., Omura, M., \& Suzuki, N. (1967) IE tenkai no tameno kiso ron. Indasutoriaru enjiniaringu, 9(6), 538-545.

Wada, E., \& Juji, S. (1967). IEr no yakuwari to kongo no kadai. Indasutoriaru enjiniaringu, 9(6), 518-526.

Wada, K. (2009). Monozukuri no guwa. Ford kara Toyota he. Nagoya, Nagoya daigaku shuppankai.

Yasui, T. (1986). Gendai daikogyo no rodo to kanri. Tekko konbinato no keiei keizaigakuteki kenkyu. Kyoto, Mineruva shobo.

Yawata seitetsu kabushiki gaisha shashi hensan iinkai. (ed.) (1981) Hono to tomoni. Yawata seitetsu kabushiki gaishashi. Shinnihon seitetsu kabushiki gaisha, Tokyo

Yawata seitetsusho shyoshi hensan jikko iinkai. (1980). Yawata seitetsusho hachijunenshi. Bumonshi, gekan. Kitakyushu, Shinnihon seitetsu yawata seitetsusho.

Zeitlin, J. (2000). Introduction: Americanization and its limits: Reworking US technology and management in post-war Europe and Japan. In: Zeitlin, J. \& Herrigel, G. (eds.) Americanization and its limits. Reworking US technology and management in post-war Europe and Japan. Oxford, Oxford University Press, pp 1-50.

\section{Copyrights}

Copyright for this article is retained by the author(s), with first publication rights granted to the journal.

This is an open-access article distributed under the terms and conditions of the Creative Commons Attribution license (http://creativecommons.org/licenses/by/4.0/). 